\title{
JEAN GOTTMANN'S ATLANTIC "TRANSHUMANCE" AND THE DEVELOPMENT OF HIS SPATIAL THEORY
}

\author{
LUCA MUSCARÀ ${ }^{1}$
}

\begin{abstract}
“...territory, although a very substantial, material, measurable and concrete entity, is the product and indeed the expression of the psychological features of human groups. It is indeed a psychosomatic phenomenon of the community, and as such is replete with inner conflicts and apparent contradictions." (GOTTMANN, 1973: 15)
\end{abstract}

\begin{abstract}
This paper analyses Gottmann's spatial model in relation to his complex biography which took place during some of the great historical changes of the $20^{\text {th }}$ century. In particular, it relates the concept of Megalopolis to his theoretical writings in political geography. The development of the latter ones could not be fully understood without reference to his "transhumance" between the two sides of the Atlantic from 1941 to 1961.
\end{abstract}

Key-words: Gottmann, atlantic transhumance, spatial theory, Megalopolis, political geography.

Résumé: LA “TranShUMANCE” ATLANTIQUe DE JEAN GOTTMANN ET LE DEVELOPPEMENT DE SA THEORIE SPATIALE - Cet article analyse le modèle spatial de Jean Gottmann en relation avec sa complexe biographie, tout au long de certains des grands changements du $\mathrm{XX}^{\mathrm{e}}$ siècle. Nous développons, en particulier, la relation entre le concept de Mégalopolis et ses écrits théoriques en géographie politique. Le développement de la pensée de Gottmann doit prendre en compte, pour être compris, sa "transhumance" entre les deux côtés de l'Atlantique qui a eu lieu de 1941 à 1961.

Mots-clés: Gottmann, transhumance atlantique, théorie spatiale, Megalopolis, géographie politique.

Resumo: A "TRANSUMÂNCIA" ATLÂNTICA DE JEAN GOTTMAN E O DESENVOLVIMENTO DA SUA TEORIA ESPACIAL - Este artigo analisa o modelo espacial de Jean Gottman, relacionando-o com a

1 University of Trieste. Sistema Terra. Via Tiburtina, 965-00159 Roma, Italy. Tel.: 3906 40793909; Fax: 3906 40793973; E-mail: muscara@unive.it 
sua complexa biografia, ao longo de algumas das grandes mudanças históricas do século XX. Dedicaremos particular atenção à relação entre o conceito de Megalópolis e os seus escritos teóricos de geografia política. O desenvolvimento do pensamento de Gottman não pode ser cabalmente compreendido sem integração da sua "transumância" entre os dois lados do Atlântico, de 1941 a 1961.

Palavras-chave: Gottman, transumância atlântica, teoria espacial, Megalópolis, Geografia política.

\section{INTRODUCTION}

The contribution of Jean Gottmann (Kharkov, 1915 - Oxford, 1994) to the geographical thought of this century is generally attributed to his concept of Megalopolis (JOHNSTON, 1996). Originally developed for the study of the highly urbanized North-Eastern seaboard of the United States (GOTTMANN, 1961b), this concept of urban geography was subsequently applied to other parts of the world, particularly to Japan (MIYAKAWA, 1996) and Europe (C. MUSCARÀ, 1978). The international success of Megalopolis may have paradoxically obscured his political geography writings, with a few exceptions (CAMU, 1956; BUTTIMER, 1971; ROBIC, 1992; HUBERT, 1993; PREVELAKIS, 1996a)².

The reason for this apparent gap between his urban and political geography could be found in the circumstances that brought him to lead a "transhumant" life between the two sides of the North Atlantic for over 20 years (Tab. 1). This transhumance is mirrored by the linguistic nomadism between the French and English languages through which he developed his vast scientific production (fig. 1). His bibliography counts a conspicuous record of about 400 publications translated in 15 languages over 60 years of intellectual activity. Excluding a few duplicates, we have counted around 150 publications in French and 180 in English ${ }^{3}$. This transhumance between France and the USA explains also why in his scientific career Gottmann ended up with two distinct and often non-geographic audiences: the public of international relations' specialists, he reached through his political geography writings and teaching 4 , and the urban planning/architecture community that became aware of his ideas with the success of Megalopolis and his following activity with Doxiadis' Ekistics movement.

This paper analyses Gottmann's spatial model in relation to his complex

2 After his death, there has been an effort in Europe to rediscover his political-geographical thought, his powerful general concept of "iconography" and his "circulation/iconography model" (PREVELAKIS, 1996b; L. MUSCARÀ, 1996 and 1998a; HUBERT, 1998).

${ }^{3}$ His 1933-1983 official bibliography is published in Patten, J. (ed.) 1983 and in Gottmann, J. 1983b. An updated version of it, including the publications for the years 1983-1994, can be found on Cybergeo (L. MusCARÀ, 1998b). Two of his major theoretical books (GotTMAnN, 1952a, 1973) were published

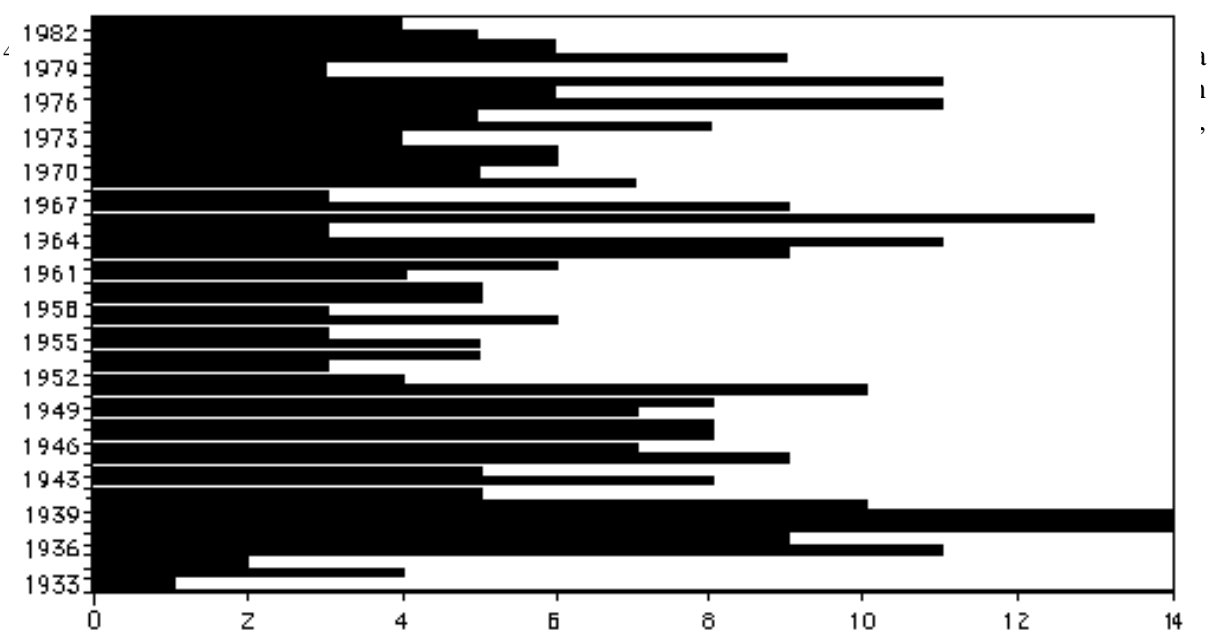


biography which took place during some of the great historical changes of the $20^{\text {th }}$ century. In particular, it relates the concept of Megalopolis to his theoretical writings in political geography. The development of the latter ones could not be fully understood without reference to his "transhumance" between the two sides of the Atlantic from 1941 to 1961.

Fig. 1 - Gottmann's bibliography, 1933-1982 (books are counted as one).

Fig. 1 - Bibliografia de Gottmann, 1933-1982.

(os livros estão contabilizados como uma unidade)

\section{THE SPATIAL THEORY OF JEAN GOTTMANN ${ }^{5}$}

The goal of geography is to explain the partitioning of the world and in order to do so, Gottmann introduced a couple of contraries that work together as a binary model: a material component and a psychological component. Thus, the political partitioning of geographical space is the product of the interactions between the forces of external change (circulation), which move people, merchandise, ideas or information, and the sets of territorial-related symbols and beliefs' systems (iconographies) that human communities create and hand down in order to build a group identity, resist to an excess of change and stabilize the territory to a "common mooring" (1966b: 31).

As his methodological article shows (1947) - the original inspiration for this opposite couple is of antagonist forces as the key to explain living reality in terms of dynamic tendencies rather than of permanent states (BERGSON, 1909: 13).

His binary model could be connected with a second couple of contraries, which Gottmann learned from the study of classic philosophy and history, and that he frequently quoted as clarifying examples. One is the ideal city-state of Plato, that represents a close, protected, self-sufficient system. The other is the Alexandrine network of cities, that works as an open system. Both cases introduce a discontinuity between the inner and the outer space that affects the circulation inside and outside the differently limited space, finally influencing the openness or closeness of a given territory ${ }^{6}$. In order to guarantee a relative stability, Plato recommends to locate the city

5 Gottmann's theory of geographic space found its first full formulation in the early fifties (1951-52a, b) to be successively completed (1966b, 1973, 1975, 1980a, 1980b, 1980c, 1982, 1983a, 1983b, 1994). Nevertheless it should be noted that it was already expressed in mature form before his study on Megalopolis.

6 This accent on an inside and outside was derived from $19^{\text {th }}$ century French biologist Claude Bernard's Introduction à la medicine experimentale, who explained life as a balance between an inner milieu (the organism) and an outer milieu (the environment). Gottmann made reference to it in his 1947 fundamental article. Bernard's two milieus anticipate the current theories on complex eco-systems (e.g. MORIN, 1980) and on structural coupling between living systems and their environment of contemporary theoretical biology (MATURANA and VARELA, 1980). 
far from the sea, considered as a major vector of changes, thus placing a strong partition between the inside and the outside of his territory (Laws, 4704-5737), while the Alexandrine network of cities is characterized by a high accessibility to the waterways. The ideal city-state could be seen as a model based on an "iconographic" supremacy. Symmetrically, in the Alexandrine web of cities the circulation is the prevailing factor.

The oscillation in history between close and open territorial systems was explained by Gottmann with the continuous swinging between another couple of contraries: the need for rescue and safety on one side and the search for resources and opportunities, which characterize human communities on the other?

Table 1: Schematic representation of Gottmann's spatial theory ${ }^{8}$.

Quadro 1: Representação esquemática da teoria espacial de Gottmann.

\begin{tabular}{|c|c|c|c|c|}
\hline \multicolumn{2}{|c|}{ Human Community } & \multicolumn{2}{|c|}{ Effects on Geographic Space } & \multirow[t]{2}{*}{ Classic Models } \\
\hline (need for) & (reinforces) & $\begin{array}{c}\text { (that in turn } \\
\text { asks for) }\end{array}$ & $\begin{array}{l}\text { (the territory } \\
\text { will) }\end{array}$ & \\
\hline rescue & iconography & partitioning & close & Plato's city-state \\
\hline opportunities & circulation & accessibility & open & Alexandrine cities' network \\
\hline
\end{tabular}

As stability is more a tendency than a state, an eccess of circulation could paradoxically call for a reinforcement of the iconographies, ending up with restrictions on accessibility and further partitioning (L. MUSCARÀ, 1998a).

Since the political partitioning of the world was not just an abstraction, but a concrete experience in his real life, he knew that the greatest concentration of resources and opportunities was to be found in the city, as he focused on the concept of carrefour from French classic geography. The carrefour not only was the place where circulation and iconography met, but became the inner key that led him to identify an urban region at an unprecedented scale. Beyond the political map, the American experience made him aware of the scale of the urbanization process. The formation of urban densities as network of carrefours was the new pattern of settlement of the human communities in that part of the world. But this urban network of transactional activities, of communication and transport flows and infrastructures was kept together more than anything by the common trust of its community.

This meant a shift from the political geography of the nation-states, typical of the Old World, to a political geography at the urban scale, typical of the New World: a geography of dots and lines, of flows, nodes and networks stemming from the interaction

\footnotetext{
7 A swinging that may recall the bipolarism of the limbic system, responsible for emotions in human brain.

8 This representation is derived from the preparatory work for an announced symposium on the "Circulation factor", subsequently canceled due to political reasons. See also Hubert (1998).
} 
of the concrete needs of the communities. This fact explains why there is no substantial discontinuity between his writings in political and urban geography, but rather an evolution of the latter from the first. Territory is a "psychosomatic phenomenon" and its partitioning takes place first of all in "people's minds" and subsequently in geographic space: "Nous retenons que le concept de territoire avec ses composantes matérielles et psychologiques est un expédient psychosomatique nécessaire pour préserver la liberté et la variété des communautés séparées dans un espace interdépendant et accessible." (GOTTMANN, 1975: 46-63) .

In social science it was always difficult to transpose deductively psychological issues from the individual scale to a collective scale overcoming the limit of a small group, because of the risk of social determinism and of the extreme complexity of the social matter. Gottmann's iconographies can be considered as a rare example of the capacity to bridge the gap between the individual and the collective dimension. Since the French geographer did not adventure himself on abstract territories without always keeping an eye on the geographic reality, his search for theoretical generalizations could never be accused of excessive abstraction. It would be interesting to follow the interplay of the circulation and iconography factors in his dense biography. We have attempted to do so, in our dense reconstruction of the first part of a life lived at full, until the publication of Megalopolis. ${ }^{10}$

\section{THE YEARS FROM 1915 TO 1941}

Jean Gottmann was born as Russian citizen from a well-off Jewish family in Kharkov - a large trading and industrial city of Ukraine - thus belonging simultaneously to a national community and to a very special minority, which found the reasons of its identity more in the a sharing of a common religion and traditions, than in a national territory. In 1918 during the turmoil following the October revolution, Gottmann's

9 "We believe that the concept of territory, with its material and its psychological components is an psychosomatic expedient necessary to preserve the freedom and the variety of communities separated in an interdependent and accessible space". (Our translation). On psychosomatic territory see also: Gottmann, 1973: 15; 1983: 315 and 1993: 201.

10 The reconstruction of his biographical record, was based on four major sources:

- Entretiens d'Oxford, a transcription of the 1993 Oxford interviews realized by Marie-Claire Robic e Jean-Louis Tissier;

- Oral History, a transcription of an interview realized at Columbia University in New York;

- Neil Smith's Interview with Jean Gottmann, March 23th, 1982.

- The Fond Gottmann, at the Département des Cartes et Plans of the Bibliothèque Nationale de France and in particular his 1940 - 1960 agendas, his correspondence with Michael Berchin, Isaiah Bowman, Orlando Ribeiro, Paul Mantoux, Henri Morel, and other documents, including his 1941-45 passport and his application form to the United Nations of 1946. Other biographical sources could be found in some of his books and articles (GotTMAnN, 1968, and 1990a). Some biographic information was in part collected during meetings and written correspondence with Jean Gottmann. A great help came from Madame Bernice Gottmann, Calogero Muscarà, Yasuo Miyakawa, Suzanne Daveau and Jean-Yves Sarazin, curator of the Fond Gottmann at the BNF in Paris, who I would like to thank for their support. 
parents were both killed ${ }^{11}$. Adopted by an aunt and her husband, together with his grandfather Kelman Gottmann, after a period of unsettlement (Sebastopol, Istanbul) he migrated to France, sailing to Marseilles and settling down in Paris in 1921.

Michael Berchin - his adoptive father - had received rabbinical education, but rather became a journalist. In the 30s he was active in the Zionist Revisionists Movement and in the Russian-émigrés community in Paris (GOTTMANN, 1952c). Gottmann received a French traditional education (Ecole communale, Lycée Montaigne, Lycée Saint Louis) and from the early 30s, began to study at the Institut de Géographie in rue St.Jacques, under Vidal's scholar Albert Demangeon. In 1933, he had the first opportunity of visiting Palestine. His master had proposed him to write a thesis on Paris' milk distribution system, but instead he convinced him to let him work on irrigation systems in Palestine. This study case allowed him to conjugate the political interests he inherited from his family with his scientific interests in the tradition of the French school of geography. The position of Palestine within an arid region became an opportunity to reject scientifically the geographic determinism that was then dominant in the German and in part of the American schools of geography (E. Huntington) in his early essay of 1937.

At about this time, he found in the readings of Turner and Bowman a first geographic concept where psychology played a fundamental role: the pioneer fringe of colonization, and at the Amsterdam IGU Congress in 1938 he discussed its application to the study of Palestine with Bowman himself.

While his adoptive parents were still in France with a passport of "apatrides", in 1939 Gottmann was finally able to obtain French citizenship. By his own admission (1990a: 22), Gottmann was then thinking of his future as that of a geographer specialized in the cultures of the Mediterranean, but the outbreak of World War II, with the nazi invasion of France, the promulgation of racial laws and the death of his master Demangeon brought a radical change to his academic plans and life, interrupting his French career. The correspondence between the young Gottmann and his Portuguese friend and colleague Orlando Ribeiro, illuminates the understanding of this obscure period. The Paris home was abandoned and in the summer of 1940 he escaped with his family to Southern France. While his parents moved to New York in the summer of 1941, he rejoined them by the end of that year, after a long Atlantic sailing, leaving behind a European continent in a war, his French academic career and the lights of the Lisbon harbor.

\section{THE ATLANTIC TRANSHUMANCE}

At about the time of his landing, in December 1941, the United States had just

${ }^{11}$ In the Biographical notes on Michael Berchin we read: "Several people in his family, some very close to him, were killed either by the Reds or by the Whites. [...] he went to Sebastopol [...] where he found most of what was left of the Gottmann family. There in 1919 Michael Berchin married Emily Gottmann [...] Together they adopted de facto a little nephew, son of Mrs. Berchin's brother, whose parents had been killed in Kharkov in 1918”. (1952c: 3). 
entered the war and Gottmann, with the help of some acquaintances at the Rockefeller foundation, got a fellowship at the Institute of Advanced Study (IAS) in Princeton. At that time the government was forming a brain trust from the universities to contribute to the war effort and Gottmann, aged 26, was brought by his dean Earle to Washington, D.C. as a "French geographer specialized in the Mediterranean region", to consult for the War cabinet. The years of the war were spent as a true citizen of Megalopolis: in 1943 he commuted weekly between Princeton and Washington, D.C., stopping also in Baltimore, where Bowman, president of Johns Hopkins University, hired him as assistent professor of geography. In a dialogue with Bowman himself, from the Entretiens d'Oxford, we learn that Gottmann starts to reflect on the singularity of his American experience, where the different engagements of his busy life are located within a network of cities, as opposed to his former life in France where everything was concentrated in Paris. This experience gave a start to his reflection on the two opposite models of settlement that are to be found on the two sides of the Atlantic, which was later developed in his spatial theory and eventually led him to the concept of Megalopolis (ROBIC and TISSIER, 1994: 22 and 67).

Forced by the war to migrate and settle down in a new environment, living and working among four poles of a same city separated by a distance of many hundreds kilometers, Gottmann was still thinking of himself as French ${ }^{12}$ and waited for the time to return to France. The first opportunity was given by a mission for the French Ministry of National Economy (Cabinet Mendès-France) through his relations in Washington ${ }^{13}$. But his center was still located in the United States.

Back in New York in July 1945, he spent about a year at the newborn United Nations as Director of Research and Studies. During this experience he traveled back to Europe once in a mission to Monaco's Hydrographic Conference. Spending a few days in Paris on that trip, he had the chance to reconnect to the Institut de Geographie and see De Martonne, then director of French Council of Scientific Research (CNRS), who invited him to start again his collaboration with the Annales de Géographie. The result was a theoretical article that can be considered the first attempt to formulate his spatial theory (1947). In this paper, Gottmann focused on the future first factor of his spatial model, the circulation. The interest for the psychological component was expressed in

12 In an unpublished interview by Neil Smith, recorded in March 1982 we read: "[Bowman] said to me: 'You should become an American citizen'. And I said to him [...] I understand what's happening, I understand that America is going to rule the world and that France had been trampled, but I'm French, I'm French cultured, different culture. I feel that I can be of some help with transAtlantic relations and so forth, but I want to keep my French nationality even if I do my career here in America".

13 In his personal papers at BNF, we can read three mission orders: I. 20 April 1945. Object: inquire for the economic services and by different personalities of industry and agriculture at Rennes, Angers and in the départements d'Ille et Vilaine, Mayenne, Finistère, Morbihan and Côtes du Nord (now Côtes d'Armor); II. 16 May 1945. Object: inquire on the situation and the possibilities of French air force; III. 9 June 1945. Object: return to "Washington" to resume his position at the "Conseil français des approvisionnements". Departure programmed "around the 10 July 1945 at the latest". 
his proposal for a geography of consumption.

That same year, realizing that a career within the UN wouldn't have allowed him to pursue his scientific interests, he left that position. But at the beginning of 1948 he was fired by Bowman ${ }^{14}$.

Having lost his main source of academic identity as geographer in the States ${ }^{15}$, Gottmann returned to Paris in June 1948, where De Martonne was giving him a position of chargé de recherche at $\mathrm{CNRS}^{16}$. In the meantime his father's dream of a promised land for the Jewish community came true and Berchin moved to the newborn state of Israel invited by Begin, leaving Gottmann without family ties in the States. In France he wrote a book on the geography of the USA for the French public, L'Amérique, (1949), but his transhumance between the two coasts of the Atlantic was just about to enter its peak.

From May to October 1949 Gottmann taught at the summer school of Columbia University. During that period he wrote for the American public the book A geography of Europe (1950). In November 1949 he received from Chapsal - an old school friend before the war - a temporary teaching at the Institut de Sciences Politiques (SciPo) in Paris. From August 1950 to the end of that year he returned with a new fellowship to Princeton's IAS. 1951 was spent entirely in France, with the only exception of a trip to Israel to visit his father. Still teaching at SciPo, he consecrated that summer to write his first theoretical book La Politique des Etats et leur géographie (1952a), where he developed his binary model to explain the partitioning of inhabited space, based on the two opposing factors of circulation and iconography (1952a: 215-222). That same year he tried to obtain the position of maitre de recherche at CNRS, but De Martonne proposed him a "deal" that Gottmann could not accept ${ }^{17}$. Subsequently, in January 1952, he returned to the USA. But a month later, while visiting the United Nations with Chapsal, a bad accident to his neck, almost paralyzed him and kept him in bed for a few months. Forced to stop and rethink to his path (ROBIC and TISSIER, 1994: 91), in the

${ }^{14}$ In a private correspondence Neil Smith suggested a possible reason for this: "Bowman hired Gottmann and was very impressed by him but the chair of the Geography Department at the time George Carter - was both jealous of Gottmann and concerned that with all his other activities in Washington, D.C. and New York and Princeton, he was not spending enough time at Hopkins. Bowman decided to fire him.'

15 Still from the same source we learn that he had a contract with Holt for a book on Europe and was able to get some funding by the Rockefeller Fundation to gather data for the book in Europe.

16 In the same interview by Neil Smith, we read: "In June, it was either June or early July, 1948. I was leaving Hopkins, and in a way I was leaving America. Of course I knew I would be coming back and so...but I had been offered a job in Paris and I was returning to France to resume a normal academic career in France".

17 Regarding this episode, in the Entretiens d' Oxford (RoBIC and TissieR, 1994: 21-2) we read: “[...] ayant fait ma demande en l'été 1951 le président de la commission de géographie au CNRS d'alors, de Martonne, m'appela pour me dire: “Gottmann il n'est pas question de vous nommer maître de recherche. La question est de savoir si on vous renouvelle ou non pour 3 ans. Et je dois vous dire que dès qu'on prononce votre nom il y a une levée de boucliers". Alors il me mit un marché en mains: pendant les 3 années à venir je ne devais pas voyager en dehors de France, et je ne devais pas publier si ce n'est sur le sujet de la thèse inscrite." 
Mount Sinai Hospital he is visited by Flexner, the new dean at Princeton, who provided him with a new fellowship to IAS. Flexner also introduced him to Paul Mellon, who will fund his geographical study on Virginia. At the beginning of 1953, he returned to Paris to teach at SciPo, while the second semester of 1953 and 1954 were entirely spent in the States to write the book Virginia at Mid-century, the first attempt of regional monograph in the French geographic tradition for a region of the USA.

1955 opens with a new semester at SciPo in Paris, but at this point his path is clear. In August of the same year he was back in New York, where he stayed until April 1956. After another return to France, from the end of 1956 to 1961 Gottmann, then in his forties, settled for a longer time in the U.S., while researching at Megalopolis under the auspices of the XX Century Fund, shifting the center of his life and of scientific interests to the USA, and traveling to Paris, Europe or Israel just one month a year.

The Atlantic transhumance (Tab. 2) started first as a forced migration from France to the United States (1), even if in his personal iconography he was still considering himself French. A temporary return to his home land in a war mission was not sufficient to make him move his center from the States, despite an interesting offer by Pleuven (2). During a "recognition" trip on UN mission he was still US-centered (3). A possible shift back to Paris with an attempt of reinstating in the French academy (4) provided him with a possibility of giving best value to his trans-Atlantic experience in terms of exchanges between the two worlds (5-6). After the accident, he returned to France (7), and tried to re-establish a balance between the two sides of the Atlantic (8-9). At that point he understood that the centrality in his life and studies was to be

Table 2: Jean Gottmann's Atlantic “Transhumance”, 1941-1959.

Quadro 2: "Transumância” atlântica de Jean Gottmann, 1941-1959.

\begin{tabular}{|c|c|}
\hline $\begin{array}{l}\text { 1. Escapes from occupied France } \\
\text { 11 Nov. 1941: } \\
\text { 4 Dec.1941: }\end{array}$ & $\begin{array}{ll}\text { * } & \text { Departs from Lisbon (from Marseille through Spain) } \\
* \quad \text { Arrives in New York (Ellis Island until } 12 \text { December) } \\
\text { * Writes on North Africa and on the Italo-Yugoslav frontier region. } \\
\text { * Ab "Bugeaud, Galliéni, Lyautey and the development of French } \\
\text { Colonial Warfare" and on Vauban. } \\
\text { * Ass. prof. of geography at The Johns Hopkins Univ. in Baltimore. }\end{array}$ \\
\hline $\begin{array}{l}\text { 2. Mission for Mendès-France } \\
\text { 11-22 Feb. 1945: } \\
\text { 12-18 July 1945: } \\
\text { 18 July } 1945 \text { - } 1 \text { Feb. 1946: }\end{array}$ & $\begin{array}{ll}\text { * } & \text { To Paris, via Liverpool, London, Dieppe } \\
\text { * In NY (via London, Lisbon) to Washington's French Supply } \\
\text { Council } \\
\text { * Reports on raw materials, interntl. trade \& economic planning in } \\
\text { US } \\
\text { * Writes U.S., French and Soviet geography during wartime } \\
\text { * In } 1945-6 \text { in New York at United Nations } \\
\text { * Teaches part-time at Johns Hopkins in Baltimore }\end{array}$ \\
\hline $\begin{array}{l}\text { 3. U.N. Mission to Monaco } \\
16 \text { April 1947: }\end{array}$ & 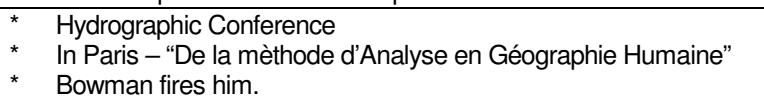 \\
\hline $\begin{array}{c}\text { 4. Returns to Paris (1) } \\
\text { 9 June 1948: }\end{array}$ & $\begin{array}{ll}* * * & \text { Chargé de recherche at CNRS } \\
* & \text { Departs from New York on board "Queen Mary" to Europe } \\
* & \text { Writes L'Amerique (1949). His father moves to Israel. } \\
* * * & \text { Back in NYC: Summer session at Columbia University } \\
\text { * Writes A geography of Europe (1950), in US until the end of }\end{array}$ \\
\hline
\end{tabular}




\begin{tabular}{|c|c|c|c|}
\hline \multirow{2}{*}{\multicolumn{2}{|c|}{$\begin{array}{l}\text { 5. Returns to Paris (2) } \\
\text { November 1949 } \\
\text { 8-17August 1950: }\end{array}$}} & \multirow{2}{*}{\multicolumn{2}{|c|}{$\begin{array}{ll} & \text { October. } \\
* * * & \text { Teaches at Institut de Sciences Politiques } \\
* * \quad & \text { Departs from Le Havre to New York; IAS Princeton. }\end{array}$}} \\
\hline & & & \\
\hline 6. $\mathrm{R}$ & $\begin{array}{l}\text { urns to Paris (3) } \\
\text { 4-11 January 1951: }\end{array}$ & $\begin{array}{l}* \star \\
* \star \\
* \\
* \\
* * \star \\
* \\
* \\
* \star \\
* \star \\
* \star \\
* \star\end{array}$ & $\begin{array}{l}\text { Teaches at Institut de Sciences Politiques } \\
\text { Sailing from NYC to Le Havre on board "Liberté" } \\
\text { Writes La Politique des Etats et leur Géographie } \\
\text { De Martonne and CNRS } \\
\text { Visits his father in Israel (September) } \\
\text { Sailing on board "Ile de France" to New York } \\
\text { UN accident (February 1952) } \\
\text { Elias, IAS Princeton, Mellon }\end{array}$ \\
\hline 7. $\mathrm{R}$ & $\begin{array}{l}\text { urns to Paris (4) } \\
2 \text { January 1953: } \\
\text { 30 June 1953: }\end{array}$ & $\begin{array}{l}* \\
* * \\
* * \\
* *\end{array}$ & $\begin{array}{l}\text { Teaches at the Institute de Sciences Politiques } \\
\text { Arrives in Paris (via Le Havre) } \\
\text { (In May second trip to Rome; in June to Jerusalem) } \\
\text { In New York - writes Virginia at Mid-Century }\end{array}$ \\
\hline 8. R & $\begin{array}{l}\text { urns to Paris (5) } \\
\text { 13-9 January 1955: } \\
\text { 11-17 August 1955: }\end{array}$ & $\begin{array}{lll}* * * \\
* * \\
* *\end{array}$ & $\begin{array}{l}\text { Teaches at the Institute de Sciences Politiques } \\
\text { To Paris sailing on "US Liberty" via Le Havre } \\
\text { From Le Havre on "Liberté" to NYC }\end{array}$ \\
\hline 9. & $\begin{array}{l}\text { 16 April 1956: } \\
\text { 4 July 1956: }\end{array}$ & $\begin{array}{l}* * \\
* * \\
* *\end{array}$ & $\begin{array}{l}\text { To Paris-Orly, then Rome and Tel Aviv } \\
\text { Paris-NYC by plane } \\
\text { At the end of ' } 56 \text { at XX Century Fund to write Megalopolis. }\end{array}$ \\
\hline 10. & 15 August - 17 Sept.1957: & * & To Paris via Amsterdam \\
\hline 11. & 24 May - 28 June 1958: & * & To London, Scotland, Amsterdam, Idlewild \\
\hline 12. & 21 June-19 July 1959: & * & NY - Paris - NY \\
\hline
\end{tabular}

Sources: *: Passeport 1941-45, Fond Gottmann at BNF, Paris; **: Agendas de J.G. at BNF; ***: Robic. M-C. and Tissier J-L, (1994) J. G. Entretiens d'Oxford, EHGO, Paris I

given to America, and returned to Europe just for short visits $(10,11,12)$. Finally, after the international recognition and success of Megalopolis (1961b), Fernand Braudel invited him to teach at the Ecole des Hautes Etudes en Sciences Sociales, in Paris. In 1968 Gottmann left Paris and moved to Oxford, taking the chair that once belonged to Mackinder at Hertford College' School of Geography, in his own words: " the synthesis between France and the United States", and continued to work on the evolution of world urbanization with a special interest for Japan.

\section{CONCLUSIONS}

At least twice in his life Jean Gottmann was forced to face the consequences of political, ideological or religious partitioning of geographical space. To the loss of his parents and of his Jewish-Ukrainian origins he opposed the construction of a French identity. The war ruined this plan and Gottmann had to adapt to the new circumstances, finding rescue and opportunities in the United States, but still desiring to rejoin his French identity. The Atlantic transhumance was a time of unsettlement, while he tried to keep the balance between the two worlds. Only when he understood the necessity of moving to the USA the center of his life and work, he was paradoxically able to re-enter the French academic world from the main door. This awareness was reached through a long trans-Atlantic commuting, during which he was able to change his own 
iconography, substituting to the centrality of France, that of the United States. His understanding of the territory as a psychosomatic phenomenon found its highest application in Megalopolis. Unfortunately this work was often mistaken in Europe as a praise of America, especially during the Cold War. His interest in the power of the networks of cities and in centrality as a basic fact of human geography was misunderstood through the distorting lenses of an ideological approach which, following the biblical curse of Babel and Niniva, tended to interpret the city as an "evil" place (MUMFORD, 1963) responsible for the unequal partitioning of resources. Without ignoring the ethical problems posed by contemporary megalopolitan life, Gottmann considered the network of cities that constituted the backbone of megalopolitan regions as the laboratory of a world community to come, because he knew that behind the formation of urban densities, there is an impulse to research greater resources that stems directly from human psychology.

\section{BIBLIOGRAPHY}

BERGSON, H. (1909) - L'Evolution créatrice, Alcan, Paris.

BUTTIMER, A. (1971) - Society and Milieu in the French geographic tradition. Published for the Association of American Geographers by Rand McNally, Chicago, IL: 146-9.

CAMU, P. (1956) - "L'œuvre géographique récente de Jean Gottmann". Cahiers de Géographie de Québec, Nouvelle Série, (1): 25-38.

Gottmann, J. (1937) - "L'homme, la route et l'eau en Asie sud-occidentale". Annales de Géographie, 46 Paris: 83-84.

Gottmann, J. (1947) - "De la méthode d'analyse en géographie humaine". Annales de Géographie, LVI, 301 Paris: 1-12.

Gottmann, J. (1949) - L'Amérique [Vol. I of the collection "Les Cinq Parties du Monde"], Hachette, Paris.

GotTMAnN, J. (1950) - A Geography of Europe, Henry Holt, New York.

GotTmann, J. (1952a) - La Politique des États et leur Géographie, A. Colin, Paris.

GotTMAnN, J. (1952b) - 'The Political partitioning of our World: an attempt at analysis". World Politics, IV, (4): 512-9.

GotTMANN, J. (1952c) - Biographical notes on M.C. Berchin (unpublished text, available at Fond Gottmann, BNF, Cartes et Plans).

GotTMANN, J. (1955) - Virginia at Mid-century. Henry Holt, New York.

GotTMAnN, J. (1959) - Etudes sur l'Etat d'Israël et le Moyen Orient'. Librairie Armand Colin, Paris.

GotTMAnN, J. (1961a) - "L'urbanisation dans le monde contemporain et ses conséquences politiques". Politique Étrangère, 6: 557-71. Reprinted in 1966b, charter VII.

GotTmann, J. (1961b) - Megalopolis: The Urbanized Northeastern Seaboard of the United States. The Twentieth Century Fund, New York.

GotTManN, J. (1963) - "La politique et le concret", La politique étrangère, Paris, $28^{\mathrm{e}}$ année, 
(4-5): 273-302.

Gottmann, J. (1966a) - “Géographie Politique”. In Géographie Générale - Encyclopédie de la Pléiade" NRF Gallimard, Paris: 1749-65.

GotTmann, J. (1966b) - Essais sur l'aménagement de l'espace habité, Mouton, Paris.

GOTTMANN, J. (1968) - "The growing city as a social and political process". Transactions of the Bartlett Society, 5, University College, London: 11-46.

GotTmann, J. (1973) - The Significance of Territory, University Press of Virginia, Charlottesville.

GotTMAnN, J. (1975) - “The evolution of the concept of Territory”. Social Science Information, XIV (3/4), Paris: 29-47.

Gottmann, J. (1980a) - “Confronting Centre and Periphery”. In J. GotTMAnN (ed.), Centre and Periphery: Spatial Variation in Politics, SAGE Publications, Beverly Hills and London: 11-25.

GotTMAnN, J. (1980b) - "Organizing and reorganizing space”. In J. GotTMAnN (ed.), Centre and Periphery: Spatial Variation in Politics, London, SAGE Publications, Beverly Hills and London: 217-24.

GotTMAnN, J. (1980c) - "Spatial partitioning and the politician's wisdom". International Political Science Review, 1 (4), Beverly Hills: 432-55.

GotTmann, J. (1982) - "The basic problem of Political Geography: the organization of space and the search for stability". Tijdschrift voor Econ. en Soc. Geografie, 73 (6): 340-9.

Gottmann, J. (1983a) - La città invincibile. Franco Angeli, Milan.

Gottmann, J. (1983b) - The Coming of the Transactional City. University of Maryland, Institute for Urban Studies, College Park, MD, USA.

GotTMAnN, J. (1984) - "Space, Freedom and Stability". International Political Science Review, 5 (2), Beverly Hills: 117-24

GotTMAnN, J. (1990a) - "Orbits: The Ancient Mediterrranean Tradition of Urban Networks". In Since Megalopolis. The urban writings of Jean Gottmann. The Johns Hopkins University Press, Baltimore, MA.

GotTmanN, J. (1990b) - "Urban Growth and Politics". Ekistics, 340/341, January-April: 4-10.

GOTTMANN, J. (1993) - "Le cloisonnement du monde: théories et faits". Postface à Jean-Paul Hubert, La discontinuité critique. Essais sur les principes a priori de la géographie humaine, Publications de la Sorbonne, Paris: 199-202

GotTmann, J. (1994) - Beyond Megalopolis. The Community Study Foundation, Tokyo. (Reprinted in English and Italian 1996. Sistema Terra, V, 1-2, Rome).

GotTMAnN J.; R. HARPER (1990) - Since Megalopolis. The Urban Writings of Jean Gottmann. The John Hopkins Univ. Press, Baltimore - London.

HUBERT, J-P. (1993) - La discontinuité critique. Essais sur les principes a priori de la géographie humaine. Publications de la Sorbonne. Paris.

HuBERT, J-P. (1998) - "A la recherche d'une géométrie de l'espace habité chez Vallaux, Gottmann et Ritchot”. L'Espace Géographique, 3, Paris.

JoHNSTON, R. (1996) - "Jean Gottmann: French regional and political geographer 
extraordinaire". Progress in Human Geography, 20 (2): 183-93.

Maturana H.R.; F.J. VAREla (1980) - Autopoiesis and Cognition. The Realization of the Living. D. Reidel Publishing Co., Dordrecht, Holland.

MiYAKAWA, Y. (forthcoming) - "The Orbit of Jean's Geography". In Proceedings of the Colloquium on "The European Iconographies", Paris 6-8 october 1996. (To be published in Géographie et Cultures).

Morin, E. (1980) - La Méthode, Tome II: La vie de la vie, Editions du Seuil, First Part, Paris.

MUMFORD, L. (1963) - The city in history. Hartford, Brace and World, New York.

MusCARÀ, C. (ed.) (1978) - Megalopoli mediterranea, Franco Angeli, Milan.

MusCARÀ, L. (1996) - "Innovazione tecnologica, spazio e rappresentazione. Appunti per una telegeografia”. Geotema, II, 3 (6): 46-56.

MUSCARA, L. (1998a) - "Les mots justes de Jean Gottmann”. Cybergeo, 54, Paris, 26.03.1998, 15 p. ("http://193.55.107.3/revgeo/geocult/texte/gottcorr.htm").

MUSCARA, L. (1998b) - "Bibliografia completa di Jean Gottmann 1933-1994”. Cybergeo, 64, Paris, 27.11.98, 28 p. (“http://www.cybergeo.presse.fr/revgeo/ehgo/muscara/gottbibl.htm”).

Patten, J. (ed.) (1983) - The Expanding City, Essays in honour of Professor Jean Gottmann. New York Academic Press, London: xvii-xxxv.

PREVELAKIS, G., ed. (1996a) - Les réseaux des diasporas, L'Harmattan, Paris - Kykem, Cyprus: 33. 
PREVElaKIS, G., ed. (1996b) - "La notion de territoire dans la pensée de Jean Gottmann". Géographie et Cultures, 20: 81-92.

ROBIC, M-C. (1992) - "Sur la naissance de l'espace géographique”. L'espace géographique, 2: $140-2$.

RoBIC, M-C.; J-L. TISSIER, (eds) (1994) - Entretiens d'Oxford. CNRS - Université de Paris I, Equipe EHGO, (unpublished text).

SANGuin, A-L.; G. PREVElakis (1996) - "Jean Gottmann (1915-1994), un pionnier de la géographie politique”. Annales de Géographie, 587: 73-8. 